\title{
Elektroniczny system wspomagający zarządzanie zasobami w bibliotece Wyższej Szkoły Biznesu - National- -Louis University w Nowym Sączu
}

STRESzczenie. W artykule przedstawiono kilka aspektów związanych z gromadzeniem zbiorów w bibliotece uczelni wyższej oraz zaprezentowano elektroniczny system wspomagający zarządzanie zasobami informacyjnymi w bibliotece uczelni niepublicznej. Zaprojektowany i wdrożony system nie rozwiązuje wszystkich problemów związanych z gromadzeniem zasobów, ale umożliwia sprawniejsze i efektywniejsze zarządzanie zasobami informacyjnymi oraz racjonalne dopasowanie zbiorów dydaktycznych do potrzeb studentów.

SŁowA KLUCzowe: biblioteki uczelni niepublicznych, gromadzenie zbiorów, zarządzanie.

\section{Biblioteka Wyższej Szkoły Biznesu - National-Louis University}

Kilka lat temu w bibliotekach uczelni niepublicznych, m.in. w bibliotece Wyższej Szkoły Biznesu - National-Louis University (WSB-NLU), przeprowadzono badanie jakości usług bibliotecznych z wykorzystaniem zmodyfikowanej metody SERVQUAL. Wyniki zostały opublikowane ${ }^{1}$, a działania naprawcze, doskonalące oferowane usługi trwają właściwie do chwili obecnej. Lata 2005-2009 przyniosły wiele korzystnych zmian. Wdrożono elektroniczny moduł wypożyczeń. Uruchomiono elektronicz-

\footnotetext{
${ }^{1}$ M.W. Sidor, Jakość ustug bibliotecznych. Badanie metoda SERVQUA, Warszawa 2005.
} 
ny system obsługi. Użytkownicy biblioteki WSB-NLU mogą prolongować, zamawiać, rezerwować materiały biblioteczne z dowolnej lokalizacji. Ponadto system powiadamia użytkowników o zbliżającym się terminie zwrotu wypożyczonych książek i przesyła informacje o materiałach zamówionych, oczekujących na użytkownika. W roku akademickim 2006/07 prawdziwym wyzwaniem były: integracja bazy dziekanatu, działu kadr i biblioteki oraz wdrożenie elektronicznej legitymacji studenta, która jest jednocześnie kartą biblioteczną. W kolejnych latach znacznie wzbogacono biblioteki w zasoby drukowane (aktualny stan zbiorów to około 70000 woluminów) i elektroniczne. Użytkownicy mogą korzystać między innymi z baz: ABI/INFORM Complete, ISI Emerging Markets, OECD iLibrary, EBSCO, JSTOR, GMID Euromonitor International, EMERALD, SAFARI kolekcja licząca około 9000 książek w wersji elektronicznej z zakresu biznesu i informatyki. Ostatni rok akademicki to projektowanie, testowanie oraz promowanie w środowisku „Modułu Syllabusy” - nowego systemu wspomagającego zarządzanie zasobami informacyjnymi.

Od początku działalności misją biblioteki było wspieranie procesu dydaktycznego i badań naukowych prowadzonych przez pracowników i studentów macierzystej uczelni - przez gromadzenie, informowanie, organizowanie i dostarczanie odpowiednich zasobów informacyjnych z wykorzystaniem różnych nośników informacji. Misja została formalnie zredefiniowana i brzmi następująco: „Misją biblioteki WSB-NLU jest wspomaganie, wzmacnianie procesu uczenia się, nauczania i badań poprzez dostarczanie zasobów informacyjnych, usług i środowiska, które prowadzą do odkryć intelektualnych". Tak określona misja wyznacza cele biblioteki:

1) zasoby informacyjne i usługi:

- zabezpieczenie zasobów tradycyjnych i elektronicznych w zakresie dyscyplin reprezentowanych w WSB-NLU,

- promowanie roli biblioteki jako podstawowego dostawcy zasobów edukacyjnych i informacyjnych,

- integracja usług bibliotecznych i zasobów bibliotecznych w „akademickie środowisko e-learning",

- pomoc w badaniach i projektach prowadzonych przez kadrę naukową i studentów oraz prowadzenie własnych prac usługowych i badawczych,

- zapewnienie odpowiedniego miejsca do studiów i badań w dogodnym dla użytkowników czasie,

- zagwarantowanie odpowiedniej infrastruktury komputerowej;

2) ocena programu bibliotecznego:

- monitorowanie jakości usług bibliotecznych oraz efektywności programu bibliotecznego, 
- poprawa procedury wewnętrznej oceny efektywności i skuteczności biblioteki;

3) promocja i partnerstwo:

- promowanie wartości biblioteki jako centrum życia intelektualnego w środowisku akademickim i lokalnym,

- promowanie umiejętności informacyjnych niezbędnych w badaniach i praktyce,

- pozyskiwanie grup wspierających bibliotekę i jej misję,

- pozyskiwanie dodatkowych funduszy (projekty, granty),

- identyfikowanie, rozwój i poszerzanie partnerstwa, pozwalające na obniżanie kosztów, wzbogacanie zasobów i podnoszenie efektywności.

Tematem niniejszego artykułu jest innowacyjny system wspomagający zarządzanie zbiorami w bibliotece WSB-NLU. Warto wspomnieć, że biblioteka obecnie dysponuje bogatymi zasobami informacyjnymi, ładnymi pomieszczeniami bibliotecznymi, nowoczesnym wyposażeniem i fachową kadrą. Promocja odbywa się na wielu poziomach, przez różne działania, m.in. seminaria dla pracowników dydaktycznych WSB-NLU, zajęcia dydaktyczne dla studentów, prezentacje i komunikaty podczas zebrań rad wydziałów, prezentacje na konferencjach, elektroniczny system komunikowania z różnymi grupami klientów biblioteki. Nietypowe dla biblioteki uczelni wyższej są też działania kulturalno-oświatowe, takie jak prowadzenie Akademickiej Galerii Sztuki i dokumentowanie działalności w serwisie elektronicznym oraz organizowanie otwartych spotkań z ludźmi kultury, biznesu, politykami i naukowcami w ramach Instytutu Kisie$\mathrm{la}^{2}$. Galeria i Instytut Kisiela poza głównymi celami, takimi jak: promocja sztuki, edukacja kulturalna, uczenie wrażliwości, aktywnej i twórczej postawy wobec rzeczywistości, mają również inną ważną funkcję, mianowicie integrują uczelnię ze społecznością lokalną, inspirują do wspólnych działań.

\section{O problematyce gromadzenia $\mathrm{z}$ innej perspektywy}

Zasoby informacyjne biblioteki są podstawowym kryterium oceny jakości usług, satysfakcji użytkownika lub jej braku. Nie jest to jedyne kryterium, ale łączy się z innymi, takimi jak: właściwe dopasowanie, dostęp-

\footnotetext{
${ }^{2}$ Szerzej na ten temat zob. M. Sidor et al., Rola uczelni w mieście niemetropolitalnym w rozwijaniu inicjatyw i aktywności obywatelskiej, w: Rola uczelni w rozwijaniu społeczeństwa obywatelskiego, red. J. Dietel, Z. Sapijaszka, Łódź 2009, s. 235-240.
} 
ność, ilość, aktualność, szybkość dostarczania zbiorów, kryteria doboru źródeł. Sprostanie oczekiwaniom użytkowników nie jest łatwe, ale jest możliwe przez sprawny system komunikacji z klientami biblioteki oraz formalne zobowiązanie do usług, czyli wyraźne określenie w ramach planu usług, jakie oczekiwania biblioteka będzie mogła wypełnić, oraz stworzenie systemu, który przybliżałby do rozwiązań optymalnych - takich, których efektywność kosztowa spotykałaby się z jakością usług i satysfakcją użytkowników.

\section{Problem do rozwiązania}

Koncepcja elektronicznego systemu zarządzania zbiorami powstawała przez dłuższy czas i była wynikiem doświadczeń zarówno użytkowników biblioteki, bibliotekarzy, jak i nauczycieli akademickich. Pierwsi wyrażali niezadowolenie z powodu braku odpowiedniej liczby egzemplarzy oraz braku poszczególnych tytułów. Dział gromadzenia przyjmował zamówienia i ciągle weryfikował sugestie dydaktyków z katalogiem bibliotecznym, sprawdzając równocześnie, czy jest to literatura podstawowa, uzupełniająca, dla jak licznej grupy itp. Ciągłe weryfikowanie wykazów literatury wymagało sporo czasu, co przy ograniczonej liczbie zatrudnionych pracowników ma też duże znaczenie. Nauczyciele akademiccy aktualizowali i uzupełniali wykaz polecanej literatury, czasem jednak bez powiadomienia biblioteki o konkretnych potrzebach oraz bez sprawdzenia, czy publikacje znajdują się w macierzystej bibliotece. Każdy z podmiotów wykonywał swoje zadanie, ale efektywność rozumiana jako relacja między usługami i produktami biblioteki a potrzebami użytkownika pozostawiała wiele do życzenia. Pomimo starań zawodził system komunikacji, chociaż relacje i kontakty pomiędzy nauczycielami akademickimi a bibliotekarzami były dość dobre w porównaniu z innymi uczelniami.

Nauczyciele akademiccy WSB-NLU często korzystają z usług biblioteki, wspomagają dobór zasobów, uczestniczą w seminariach i innych imprezach organizowanych przez bibliotekę. Mimo to przyczyny luki komunikacyjnej mogą być typowe dla bibliotek uczelni wyższych. Należą do nich na przykład: rozszerzenie profilu kształcenia (nowe kierunki, przedmioty), zmiany programowe (nowe edycje kursów), fluktuacja kadry, brak znajomości systemu bibliotecznego, szybka dezaktualizacja treści, zbyt późne zamówienie, brak publikacji na rynku wydawniczym, znacznie zwiększone koszty gromadzenia zasobów.

Przypuszczam, iż ta sytuacja jest dobrze znana w większości bibliotek i rozwiązywana na wiele różnych sposobów. Duże biblioteki uniwersy- 
teckie, dysponujące znacznymi środkami finansowymi, mogą gromadzić kompletną listę tytułów, określoną jako kanon literatury z danego zakresu, lub też przyjąć inną politykę gromadzenia, ustaloną dla danej instytucji. Przy wysokim wskaźniku kompletności istnieje mniejsze ryzyko pominięcia ważnego dla danej dyscypliny tytułu. Pozostaje jeszcze dostosowanie liczby publikacji do potrzeb użytkowników. Jak się wydaje, w tym względzie obowiązują też różne rozwiązania i różne standardy, przydatny tu może być system kontroli wykorzystania publikacji i zamówień.

\section{Polityka gromadzenia}

Polityka gromadzenia w bibliotekach uczelni niepublicznych jest dość prosta. Wiele bibliotek niepublicznych ogranicza swoje zadania tylko do realizacji funkcji edukacyjnej, czyli zapewnienia podstawowych podręczników wspierających oferowane przez uczelnie programy dydaktyczne. Zbiory biblioteczne często stanowią tam głównie skrypty publikowane przez własne wydawnictwa uczelniane. Brakuje natomiast głębszych zasobów piśmienniczych i informacyjnych, publikacji znanych polskich i zagranicznych wydawców książek naukowych, elektronicznych baz danych.

Zupełnie inną sytuację mamy w bibliotece WSB-NLU. Kanon literatury wyznaczają treści programowe, a więc wymagane dla przedmiotów i kursów publikacje podstawowe oraz uzupełniające, natomiast kolekcję naukową jako całość tworzy się z pomocą specjalistów dziedzinowych oraz przedstawicieli pracowników naukowo-dydaktycznych. Zasoby biblioteczne wykraczają poza dyscypliny związane z prowadzonymi badaniami i z dydaktyką uczelni. Przy ograniczonych środkach finansowych szczególnie istotna jest właściwa selekcja zbiorów. Największe wyzwanie jednak stanowi zasób dydaktyczny - z powodu oczekiwań studentów, kosztów pozyskiwania księgozbiorów dydaktycznych i krótkiego czasu ich użytkowania.

Przewidywany czas użytkowania, rodzaj wydawnictwa i koszty nabycia są w tym przypadku ważnymi czynnikami przeliczników ilościowych. W bibliotekach uczelni niepublicznych nie obowiązują konkretne wskaźniki przeliczeniowe (liczba woluminów/liczba studentów), ponieważ polityka gromadzenia zależy w dużej mierze od indywidualnych możliwości finansowych poszczególnych bibliotek. Duże nadzieje biblioteki wiązały $\mathrm{z}$ masowym upowszechnieniem wydawnictw elektronicznych, ale już dzisiaj wiadomo, że mają one zalety (łatwość składowania, archiwizowania, szybkość dostępu, łatwość aktualizacji treści, elastyczność dystrybucji, nowoczesne systemy wyszukiwawcze), ale i ograniczenia. Koszty ich 
pozyskiwania ciągle rosną (koszty odpowiedniej infrastruktury informatycznej, licencji, dostępów do repozytoriów). Polski rynek wydawnictw elektronicznych też jeszcze nie dostarcza oferty, którą można by uznać za konkurencyjna, a przynajmniej alternatywna, w stosunku do tradycyjnego drukowanego podręcznika akademickiego. Nowe przedsięwzięcie PWN pod nazwą I-BUK oferuje około 1000 tytułów z różnych dziedzin, ale jest to raczej kolekcja wspierająca zasoby biblioteki, a nie zastępująca źródła drukowane. Mimo zapowiedzi redukcji roli wydawnictw drukowanych ${ }^{3}$ obserwuje się ciągle zapotrzebowanie na te publikacje. Sądzę jednak, że znaczenie wydawnictw elektronicznych (szczególnie podręczników) będzie rosło wraz z poszerzaniem oferty wydawców, elastyczną formą dostępów i oczywiście pod warunkiem znacznie niższych niż do tej pory kosztów zakupu. Planowana na przyszły rok podwyżka stawki VAT na książki, czasopisma specjalistyczne, wydawnictwa elektroniczne poważnie ograniczy możliwości szkół wyższych w zakresie zakupu piśmiennictwa naukowego i dydaktycznego.

\section{System wspomagający zarządzanie zasobami w bibliotece WSB-NLU}

Efektywność biblioteki to nie tylko stopień zaspokojenia potrzeb użytkowników (obsługiwanego środowiska), ale także efektywność kosztowa, a więc konkretne nakłady finansowe ponoszone przez organizatora. Obie te efektywności są ze sobą powiązane, co oznacza, że środki finansowe wpływają na jakość świadczonych usług i określają stopień zaspokojenia potrzeb informacyjnych. Biorąc pod uwagę te wszystkie aspekty, myśleliśmy o systemie, który byłby rozwiązaniem optymalnym, w miarę elastycznym, który pozwalałby na poprawę komunikacji, na zaspokojenie potrzeb informacyjnych środowiska, a równocześnie na monitoring efektywności kosztowej.

Realizacja koncepcji systemu wspomagającego zarządzanie zasobami wymagała synchronizacji dwóch obcych systemów, stworzenia odpowiedniego oprogramowania obsługującego wewnętrzny system syllabusów kursów i przedmiotów oferowanych w WSB-NLU oraz panelu zarządzania literaturą od strony biblioteki. Firma MAX ELEKTRONIK S.A. ${ }^{4}$ zbudowała nową funkcjonalność na podstawie systemu PROLIB, pozwa-

\footnotetext{
${ }^{3}$ Ł. Gołębiowski, E książka/book: szerokopasmowa kultura, Warszawa 2009.

${ }^{4}$ Producent systemu bibliotecznego PROLIB.
} 
lającą na realizację zapytania z systemu CODA ${ }^{5}$ do modułu OPAC WWW według ustalonych kryteriów wyszukiwawczych. Dostosowanie parametrów zapytań $\mathrm{w}$ obu systemach pozwoliło na zbudowanie ${ }^{6} \mathrm{w}$ Intranecie WSB-NLU zintegrowanego modułu, pozwalającego na poziomie syllabusów na pobieranie danych bibliograficznych z katalogu i zamieszczanie ich w wykazach literatury obowiązkowej i uzupełniającej.

Z poziomu „Literatura”, zawartego w syllabusach, jest też możliwe rezerwowanie i zamawianie publikacji $\mathrm{w}$ bibliotece, bez konieczności przechodzenia do systemu katalogu OPAC WWW. Ponadto, system rozbudowano o panel zamawiania nowej literatury i o monitorowanie stanu zamówień. Od strony biblioteki stworzono panel administratora, pozwalający na przyjmowanie zamówień, realizację oraz monitorowanie i komunikowanie się z systemem syllabusów.

\section{Założenia systemu syllabusów związane z synchronizacją wykazów literatury z systemem PROLIB}

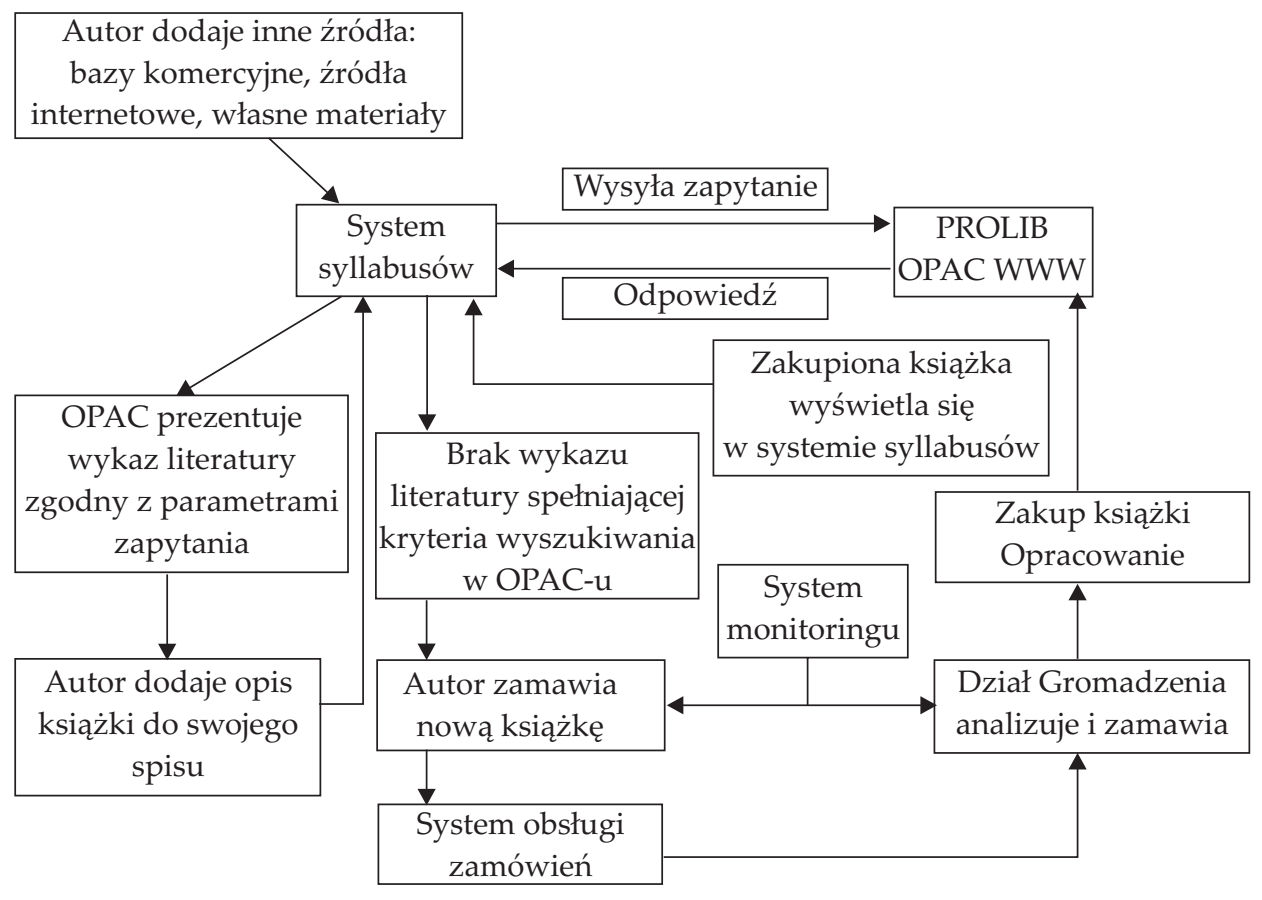

Il. 1. Model systemu

\footnotetext{
${ }^{5}$ CODA - wewnętrzny system działający w WSB-NLU.

${ }^{6}$ Oprogramowanie do "Modułu Syllabusy” wykonano w Centrum Technologii Informatycznych WSB-NLU.
} 
Taki model systemu zakłada inwencję autora syllabusów, znajomość źródeł informacji oferowanych przez bibliotekę WSB-NLU oraz ścisłą współpracę nauczycieli akademickich i bibliotekarzy. Korzyści są wymierne: maksymalne dopasowanie źródeł informacji do potrzeb edukacyjnych środowiska uczelni, łatwość aktualizacji treści oraz integracja różnych typów źródeł (drukowane, elektroniczne komercyjne, źródła internetowe, materiały własne autora syllabusa i inne).

\section{Działanie systemu}

Każdy nauczyciel akademicki zatrudniony w WSB-NLU zobowiązany jest do przygotowania elektronicznej wersji syllabusa przedmiotu, z uwzględnieniem standardowych wymogów opisu, takich jak: założenia i cele przedmiotu, opis przedmiotu, treści programowe, metody dydaktyczne, wykaz literatury podstawowej, wykaz literatury uzupełniającej, formy i warunki zaliczenia przedmiotu. Zaprojektowany system ułatwia między innymi sporządzanie jednolitych wykazów literatury. Procedura postępowania jest następująca:

1. Autor ${ }^{7}$ na stronie przedmiotu w Intranecie pod pozycją „Literatura” tworzy wykaz literatury obowiązkowej i uzupełniającej. Opisy bibliograficzne wydawnictw drukowanych są pobierane przez system syllabusów z OPAC WWW biblioteki. Odsyłacz zatytułowany „Edytuj inne materiały dydaktyczne" umożliwia autorowi wprowadzenie dodatkowych źródeł (własne materiały prowadzącego zajęcia, odsyłacze internetowe, linki do baz itp.), czyli tworzenie akademickiego środowiska e-learningu.

2. Dodanie nowej pozycji literatury odbywa się przez wpisanie jednego lub kilku parametrów książki, czyli elementów uwzględnionych w opisie bibliograficznym. Po ich zatwierdzeniu użytkownik otrzymuje listę książek z biblioteki, pasujących do podanych kryteriów wyszukiwawczych.

3. Z wykazu zaprezentowanego przez system autor syllabusa wybiera konkretną książkę za pomocą dwóch kolorowych ikonek - zielonej, gdy wskazana książka ma trafić do wykazu literatury obowiązkowej, żółtej, jeżeli ma trafić do zbioru literatury uzupełniającej; zatwierdza wybór.

\footnotetext{
${ }^{7}$ Osoba sporządzająca opis przedmiotu, wykładowca, autor kursu, zamawiający literaturę.
} 


\section{Lteratura obowiazkowa}

- ARTHUR. Jay. UWX programowanie w shello / Jay Amhur, Teo Bums; przekad $z$ jezyka angierskieg Wydawnictwo MiKOIs, 1998, 1584 83-7153-130-0 [D]

- POCZTOWSKo, Aleksy. Zarzsdzanie zssobami fodzkimi - strotegie - procesy-metody / Aleksy Pocztc

Edytuj wydawnicswa drukowane da

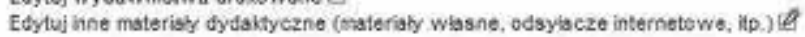

\section{: Literatura uzupełniajaca}

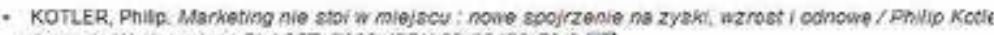
Agencjs Wydawnicza PLA,CET, 2002. ISBN B3-85428-76-3 [0]

Edytaj wydawnictwa drukowane [e

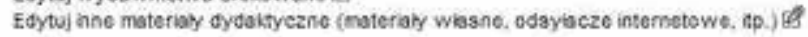

Il. 2. Literatura - fragment syllabusa przedmiotu

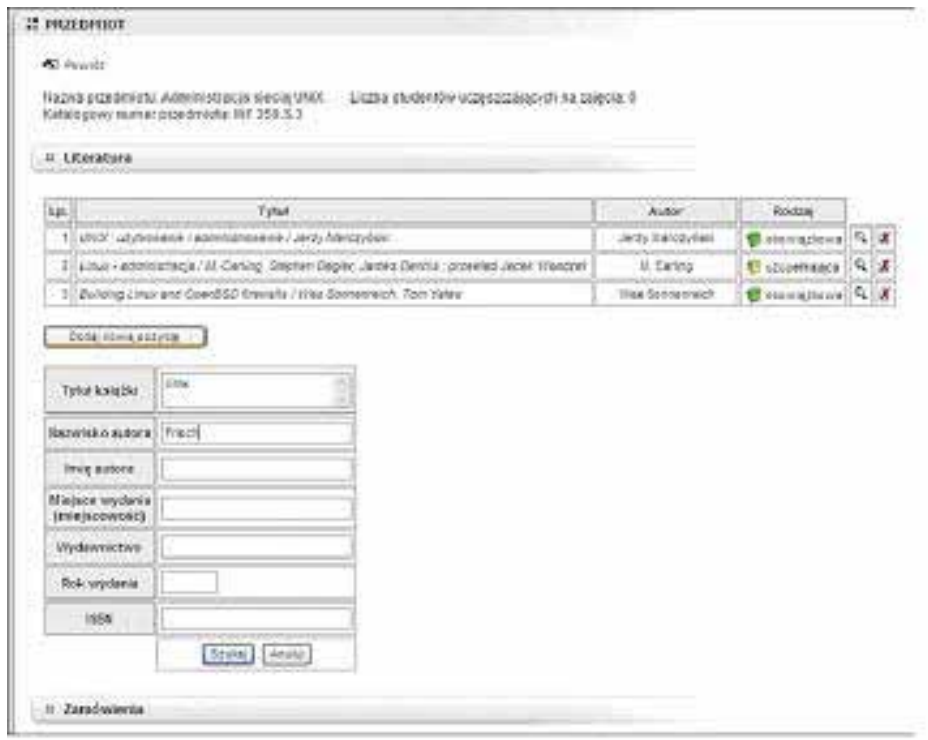

Il. 3. Wyszukiwanie i dodawanie nowej pozycji do wykazu literatury 


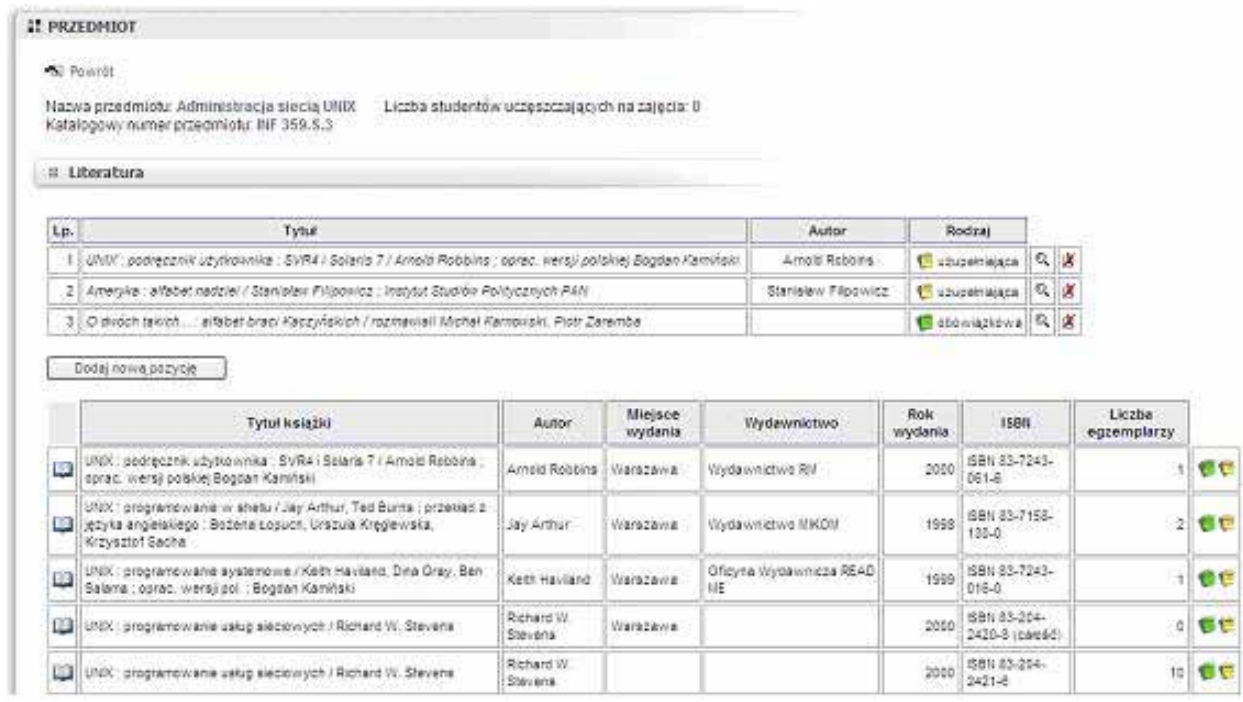

Il. 4. Wybór literatury z wykazu i zatwierdzenie

Przy wyborze książki pomocna może okazać się ikonka „,książki”, która przenosi do katalogu bibliotecznego i pozwala uzyskać dodatkowe informacje o książce oraz stwarza możliwość bezpośredniej rezerwacji lub zamówienia książki z biblioteki.

\begin{tabular}{|c|c|c|c|c|c|}
\hline Pit & \multicolumn{4}{|c|}{ 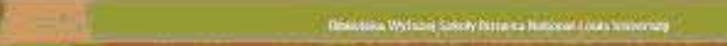 } & Prol \\
\hline \multicolumn{5}{|c|}{ 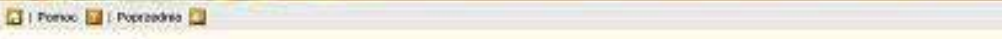 } & 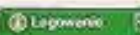 \\
\hline \multicolumn{5}{|l|}{ OPIS DCHOUMEITU } & 82 \\
\hline \multicolumn{5}{|c|}{ 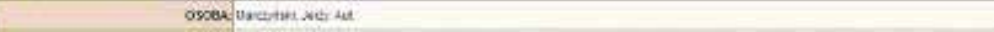 } & 12 \\
\hline \multicolumn{5}{|c|}{ 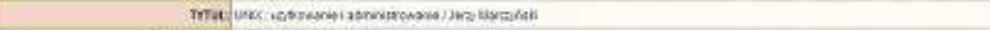 } & \\
\hline \multicolumn{6}{|c|}{ meance numbas . Henes ins } \\
\hline \multicolumn{6}{|c|}{ 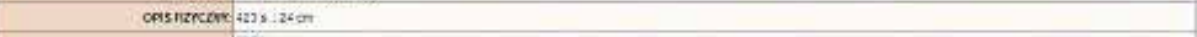 } \\
\hline \multicolumn{6}{|c|}{ 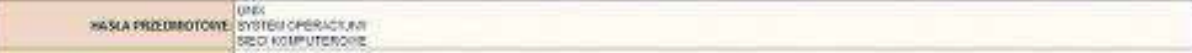 } \\
\hline \multicolumn{6}{|c|}{ 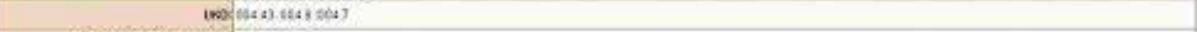 } \\
\hline \multicolumn{6}{|c|}{ 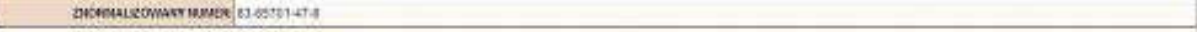 } \\
\hline \multicolumn{6}{|c|}{ 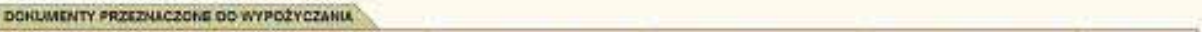 } \\
\hline matomes & 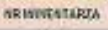 & smaunves & status & ancie & unac \\
\hline wะo & artate & $\min$ wor 7400 & Dasasion & 쑈 & $\sin$ \\
\hline
\end{tabular}

Il. 5. Automatyczne przeniesienie do katalogu bibliotecznego

Po zatwierdzeniu konkretnej pozycji opis bibliograficzny automatycznie trafia do listy książek w części „literatura obowiązkowa” lub „literatura uzupełniająca", w zależności od decyzji autora. 


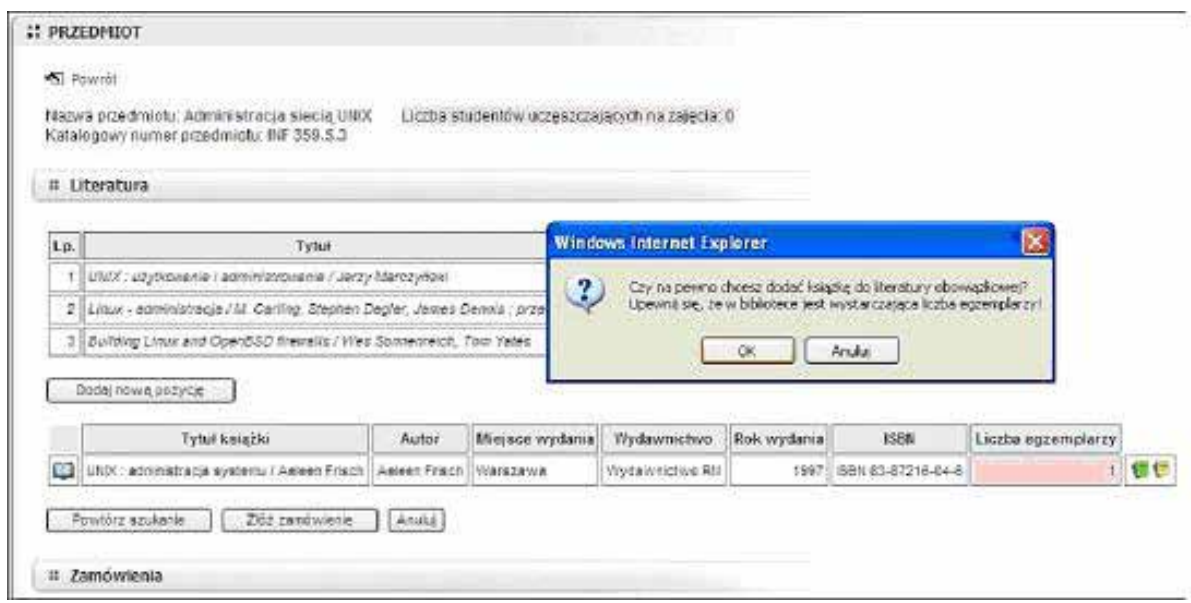

Il. 6. Dodawanie nowych pozycji do wykazu literatury

4. Gdyby system nie znalazł potrzebnego podręcznika lub znalezione pozycje nie odpowiadały autorowi (np. potrzebuje nowsze wydanie), można powtórzyć wyszukanie lub złożyć zamówienie na tę konkretną pozycję.

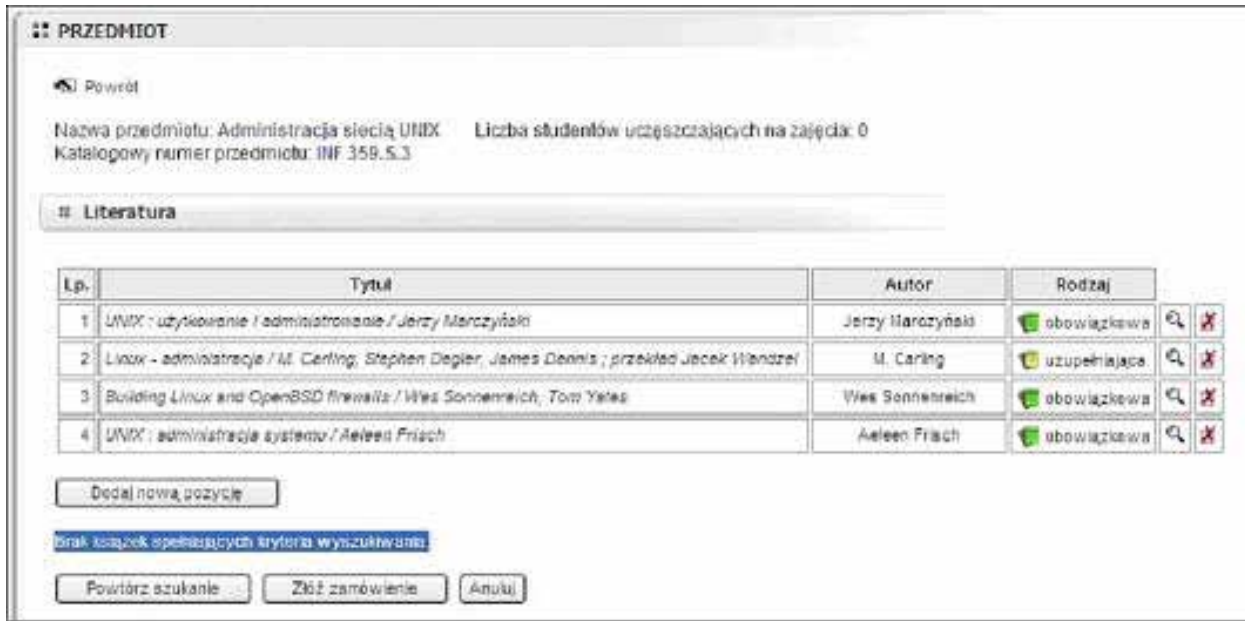

Il. 7. Powtórne wyszukiwanie lub złożenie zamówienia

Zgłoszenie prośby o zakup książki odbywa się za pomocą specjalnego formularza, na którym dodatkowo można dopisać komentarz (uwagi), dotyczący zamówienia. Ponadto, zamawiający określa, czy jest to literatura obowiązkowa, czy uzupełniająca. 

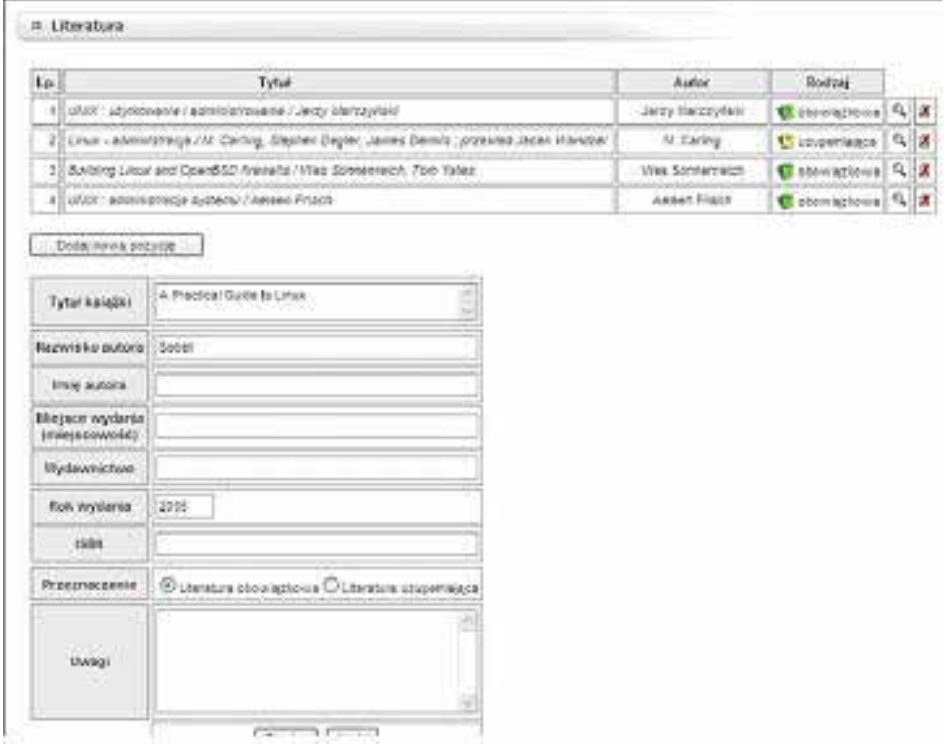

Il. 8. Formularz zamówienia

5. Autor syllabusa może też zamieścić inne źródła, korzystając z opcji „Edytuj inne materiały dydaktyczne".

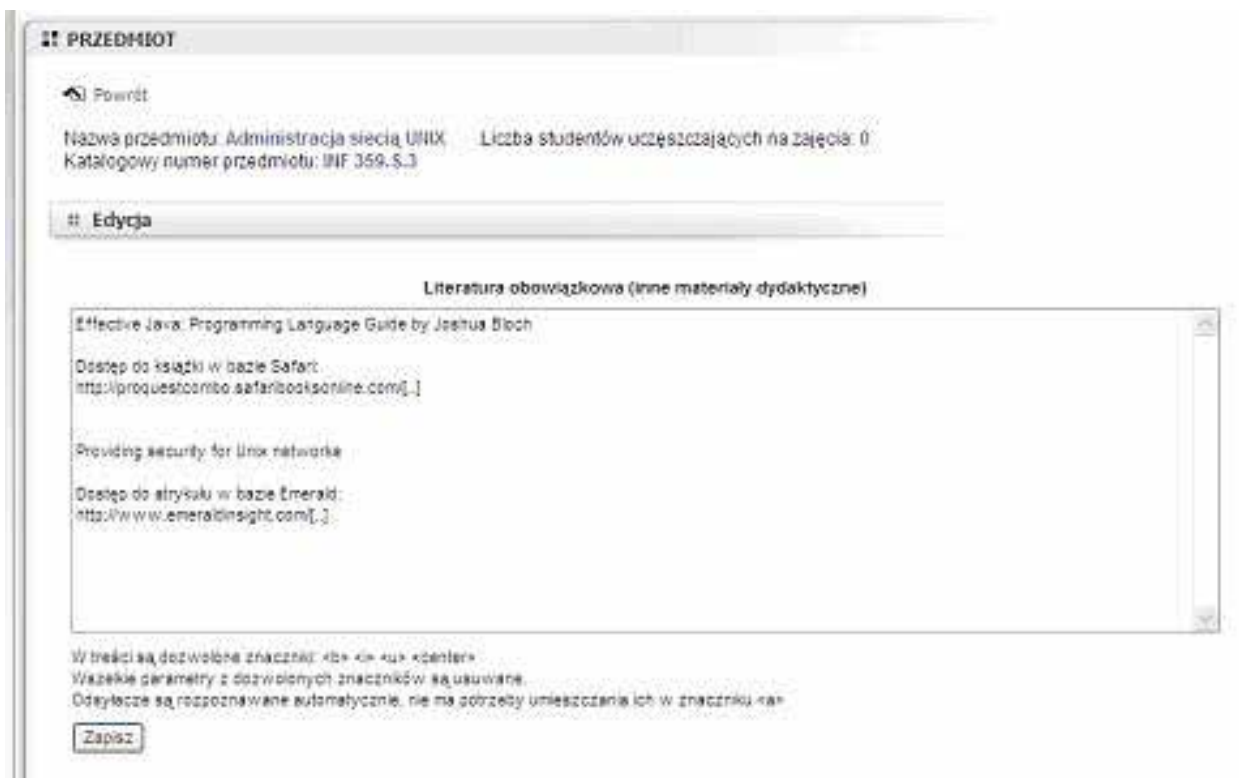

Il. 9. Inne źródła 
Użytkownik syllabusa (student, wykładowca) bezpośrednio z poziomu „Literatura” może zostać skierowany do źródeł elektronicznych dostępnych w bazach oferowanych przez bibliotekę WSB-NLU lub do źródeł internetowych (zob. il. 10-11).

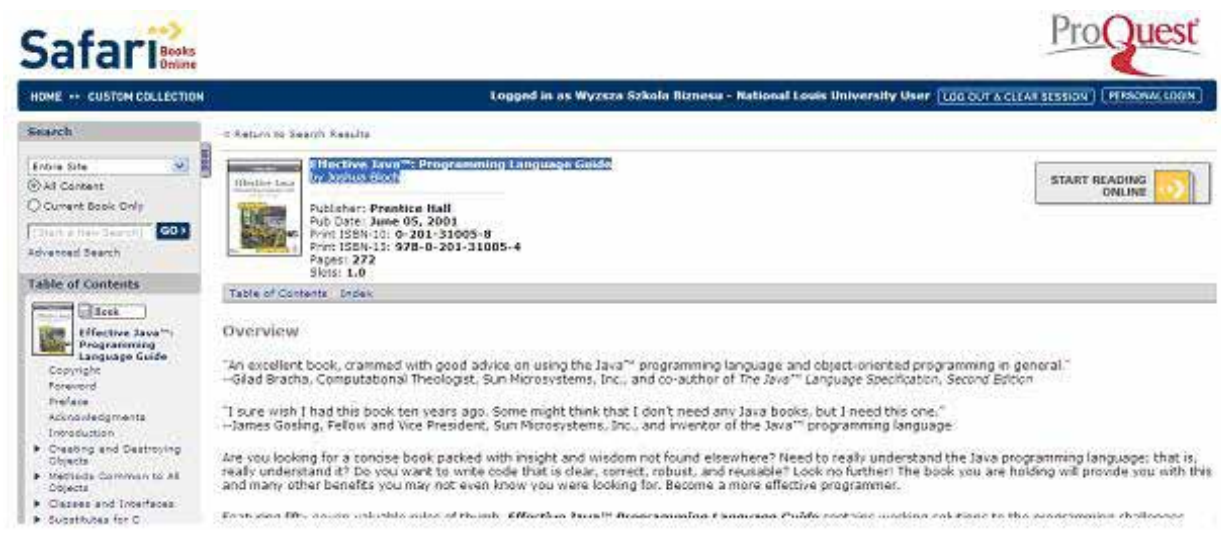

Il. 10. Inne źródła - na przykład książka elektroniczna dostępna w bazie Safari

\section{Emerald}

\begin{tabular}{l}
\hline Username: \\
WYZSZA SZKOLA BIZNESU \\
\hline My Profile \\
\hline For Administrators \\
\hline Search \& Browse \\
\hline Product Information \\
\hline Licensing Solutions \\
\hline For Authors \\
\hline For Librarians \\
\hline Research Zone \\
\hline Learning Zone \\
\hline Teaching Zone \\
\hline Support Resources \\
\hline About Emerald \\
\hline
\end{tabular}

\begin{tabular}{|c|c|}
\hline Password: & Athens/lnstitution Login / Register I Forgot Passw ord? \\
\hline Homes > Qucs Starch > Article Request & E-mail this vece \\
\hline
\end{tabular}

Article Request:

Providing security for Unix networks

\section{Add to the marked list: Session Marked List $\vee$ Go}

Article Information:

\section{Title: Providing security for Unix networks}

Author(s):Ber Stymiest

Journal:Information Management \& Computer Security

Year:1996 Volume:4 Issue:2 Page:18 - 26

DOI: $10.1108 / 09685229610793067$

Publisher: MCB UP Ltd

\section{Document Access:}

Please select from the following options

View HTMLI I View PDF (676 KB)

Il. 11. Inne źródła - artykuł dostępny w bazie Emerald 
6. Pracownicy działu gromadzenia biblioteki, za pośrednictwem specjalnego panelu, mają wgląd w stan zamówień. Pozycje z listy zamówień zawierają wszystkie informacje wpisane przez autora podczas wyszukiwania książki i dodatkowo komentarz do zamówienia wraz z informacja, czy książka trafi do wykazu literatury obowiązkowej, czy też uzupełniającej. System podaje również łączną liczbę studentów, którym dana książka będzie polecana w bieżącym semestrze lub roku akademickim.

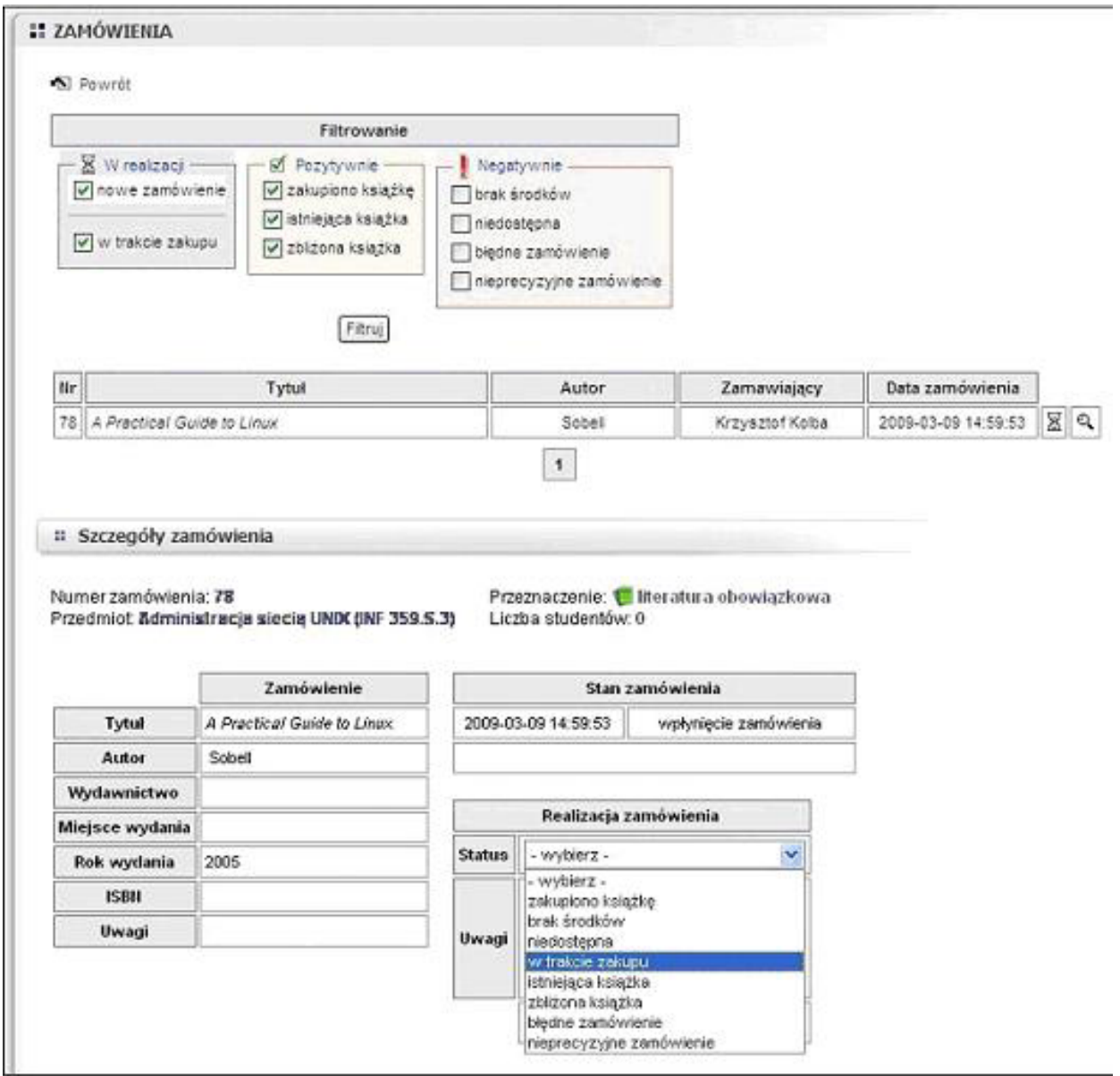

Il. 12. Panel administratora

Zamówienie otrzymuje odpowiedni status. Pozytywna realizacja zamówienia (zakup i opracowanie) powoduje automatyczne uzupełnienie na poziomie syllabusów. Autor na bieżąco może monitorować stan swoich zamówień. W przypadku negatywnego rozpatrzenia autor otrzymu- 
je informację od bibliotekarza (np. brak książki na rynku wydawniczym) i może złożyć nowe zamówienie na inną publikację.

W systemie założono ponadto parametr liczbowy, który umożliwia sporządzanie wykazów literatury występującej w niewystarczającej ilości. Funkcja ta znacznie ułatwia proces zamawiania i uzupełniania zbiorów.

\section{Moduł Syllabusy - system wspomagający zarządzanie zasobami}

System umożliwia:

- ujednolicenie opisów bibliograficznych (zgodne z PN) we wszystkich wykazach literatury przedmiotów i kursów,

- pobieranie gotowych opisów bibliograficznych (oszczędność czasu, unikanie błędów w tworzeniu opisów literatury, ułatwienie dla studentów),

- aktualizacje literatury w oferowanych przedmiotach, kursach (istotne dla studentów, gremiów oceniających),

- racjonalne dopasowanie zasobów bibliotecznych do przedmiotów kształcenia (np. w stosunku do liczby studentów),

- zamawianie, rezerwowanie materiałów bibliotecznych bezpośrednio ze strony syllabusów,

- kontrolę zasobów pod kątem potrzeb środowiska (kadry, studentów),

- monitorowanie zamówień (komunikaty zwrotne, np. brak książki na rynku wydawniczym, $\mathrm{w}$ trakcie realizacji itp.),

- integrację różnego typu źródeł informacji (elektroniczne, drukowane, własne, obce),

- sprawniejsze i efektywniejsze zarządzanie zasobami informacyjnymi.

System działa od września 2009 roku i rezultaty są już widoczne. Autorzy syllabusów chwalą łatwość obsługi systemu i możliwości integracji zasobów informacyjnych. Pracownicy działu gromadzenia natomiast dysponuja precyzyjnymi danymi o aktualnych potrzebach informacyjnych. Możliwości rozwoju systemu są duże i już myślimy o wykorzystaniu systemu w nowych funkcjach. 
MARIA WANDA SIDOR

\title{
Electronic resource management supporting system at the Wyższa Szkoła Biznesu - National- -Louis University library in Nowy Sącz
}

\begin{abstract}
Aвstract. The article discusses several aspects related to library acquisition in a library of an institution of higher learning and presents an electronic system supporting information resources management in a non-public university. Apparently, the designed and implemented system does not solve all problems related to resource acquisition, but enables a more effective management of information resources and efficient adjustment of didactic resources to the needs of students.
\end{abstract}

KEY wORDs: libraries of non-public institutions of higher learning, resource acquisition, management. 